\title{
Learning Strategies at SD Muhammadiyah 1 Candi during the Covid 19 Pandemic [Strategi Pembelajaran SD Muhammadiyah 1 Candi saat Pandemi Covid 19]
}

\author{
Arizkylia Yoka Putri*, Muhlasin Amrullah \\ \{ yokaarizkylia@gmail.com, muhlasin1@umsida.ac.id\} \\ Fakultas Psikologi dan Ilmu Pendidikan, Universitas Muhammadiyah Sidoarjo, Indonesia
}

\begin{abstract}
This Study aims to provide an overview of the trategies implemented by SD Muhammadiyah 1 Candi in the learning process during the Covid 19 pandemic. The method used in this research is descriptive qualitative method. The data collection techniques in this study were trough interviewes, documentation and observation. During the covid 19 pandemic, SD Muhammadiyah 1 Candi implemented an online learning policy, in accordane with the instructions issued by the minister of education and culture Nadiem Makarim through Circular Number 4 of 2020 concerning Implementation of Educational Policies in the emergency period of the spread of the Corona virus. Online learning is carried out in order to reduce the spread of covid-19. During the implementation of online learning, SD Muhammadiyah 1 Candi experienced several obstacles at the beginning of its implementation, namely the lack of parental education in using learning tools such as zoom meetings. From these obstacles, SD Muhammadiyah 1 Candi Provided solutions in the from of home visits and direct classes. Home visits are intended to provide more understanding to students. Direct class is a solution for students who do not have cellphones. However, during the application of online learning students are very enthusiastic in their teaching and learing activities.
\end{abstract}

Keywords: Strategy, Learning, The Covid 19 Pandemic

\begin{abstract}
Abstrak. Penelitian ini bertujuan untuk memberikan gambaran mengenai strategi yang dilakukan SD Muhammadiyah 1 Candi dalam proses pembelajaran selama masa pandemi covid-19. Metode yang digunakan dalam penelitian ini adalah metode kualitatif deskriptif. Adapun teknik pengambilan data dalam penelitian ini adalah dengan melalui wawancara, dokumentasi dan observasi. Selama masa pandemi covid-19, SD Muhammadiyah 1 Candi menerapkan kebijakan belajar secara online, sesuai dengan instruksi yang dikeluarkan oleh Menteri Pendidikan dan Kebudayan Nadiem Makarim melalui Surat Edaran Nomor 4 Tahun 2020 tentang Pelaksanaan Kebijakan Pendidikan dalam masa darurat penyebaran virus Corona. Pembelajaran secara online dilaksanakan dalam rangka menekan penyebaran covid-19. Selama pelaksanaan pembelajaran online, SD Muhammadiyah 1 Candi mengalami beberapa kendala di awal penerapannya yakni kurangnya edukasi orang tua dalam menggunakan perangkat pembelajaran seperti zoom meeting. Dari kendala tersebut, SD Muhammadiyah 1 Candi memberikan solusi berupa home visit dan kelas langsung. Home visit ditujukan untuk lebih memberikan pemahaman kepada siswa. Kelas langsung merupakan solusi bagi siswa yang tidak memiliki handphone. Namun, selama penerapan pembelajaran online siswa sangat antusias dalam kegiatan belajar mengajarnya.
\end{abstract}

Kata Kunci: Strategi, Pembelajaran, Pandemi Covid19 


\section{Pendahuluan}

Di bulan Januari tahun 2020, dunia telah dihebohkan dengan adanya wabah covid 19 yang masih berlangsung hingga saat ini. Virus yang ditemukan pertama kali di China menimbulkan dampak yang sangat besar pada beragam sektor, salah satu diantaranya adalah sektor Pendidikan. WHO menghimbau untuk memberhentikan kegiatan-kegiatan yang dapat menimbulkan adanya kerumunan. Oleh sebab itu, pemerintah mengambil kebijakan untuk tetap mengadakan sistem pembelajaran dalam jarak jauh atau pembelajaran dalam jaringan (pembelajaran online) guna mengurangi dan memutus rantai penularan virus covid 19 melalui Surat Edaran Nomor 4 Tahun 2020 tentang Pelaksanaan Kebijakan Pendidikan dalam masa darurat penyebaran virus Corona. [1]

Pada kondisi saat ini, strategi dalam pembelajaran diharuskan untuk dapat lebih mampu meningkatkan minat atau motivasi belajar siswa, karena dengan adanya masa peralihan antara pembelajaran tatap muka menuju pembelajaran daring, mengharuskan para siswa untuk mampu beradaptasi. Dalam masa adaptasi tersebut diperlukan strategi atau upaya untuk membuat anak merasa nyaman sehingga mampu menerima dan memahami pembelajaran dengan baik. Strategi pembelajaran adalah salah satu faktor utama untuk meningkatkan proses belajar. Dick [1] mengatakan bahwa strategi pembelajaran merupakan Haluan atau aspek yang digunakan untuk mendekati atau memuliakan suatu proses pembelajaran suatu mata pelajaran atau suatu kemahiran. Yatim Rianto menjelaskan bahwa strategi pembelajaran adalah siasat guru dalam mengefektifkan, mengefesiensikan serta mengoptimalkan fungsi dan interaksi antara peserta didik dengan komponen pembelajaran dalam suatu kegiatan pembelajaran untuk mencapai tujuan pembelajaran untuk mencapai tujuan pengajaran [1]

Selain strategi, motivasi belajar menjadi faktor lain yang berpengaruh dalam proses belajar, terlebih dalam kondisi seperti saat ini. Motivasi belajar adalah dorongan dari dalam diri peserta didik agar berperilaku mau mengikuti pembelajaran untuk mencapai tujuan seperti apa yang kita kehendaki atau dapat diartikan sebagai usaha memberikan dorongan yang dilakukan oleh guru terhadap muridnya dengan tujuan agar mereka mau belajar dengan rasa penuh kesadaran, semangat tinggi, keikhlasan untuk mencapai tujuan sekolahan [2]. Di samping itu, SD Muhammadiyah 1 Candi menerapkan upaya untuk membangkitkan motivasi belajar siswanya salah satunya adalah dengan bermain. Meskipun dengan keterbatasan sarana karena melalui virtual meeting atau daring, permainan sederhana mampu membuat siswa termotivasi dan bersemangat untuk mengikuti pembelajaran.

Di tulisnya karya tulis ini untuk mengetahui secara mendalam tentang strategi SD Muhammadiyah 1 Candi dalam pembelajaran di tengah pandemi covid 19. Sehingga, pembaca dapat mengidentifikasi tentang cara beserta trobosan yang diterapkan pada proses pembelajaran. Dengan adanya karya tulis ini kita bisa mendapatkan informasi tentang strategi dalam pembelajaran di tengah pandemi covid 19.

\section{Metode Penelitian}

Penelitian ini bertujuan untuk mengetahui lebih lanjut tentang strategi SD Muhammadiyah 1 Candi dalam pembelajaran di tengah pandemi covid 19. Penelitian ini menggunakan metode penelitian kualitatif deskriptif.[3] Pendekatan kualitatif merupakan proses penelitian untuk memahami masalah-masalah sosial atau manusia dengan menganalisis kata-kata untuk menciptakan gambaran kompleks dan menyeluruh, serta melaporkan pandangan informasi terperinci yang diperoleh dari para sumber informasi dalam lingkungan alami. Pendekatan kualitatif juga bertujuan untuk menyelidiki, menemukan, menggambarkan, serta menjelaskan 
kualitas atau keistimewaan dari pengaruh sosial yang tidak dapat dijelaskan, diukur, atau digambarkan melalui pendekatan kuantitatif. Teknik pengambilan data dalam penelitian ini melalui wawancara, dokumentasi dan observasi, adapun trianggulasi yang di pakai dalam penelitian ini adalah trianggulasi teknik. Penggunaan metode kualitatif ini dimaksudkan untuk memperoleh gambaran mengenai upaya untuk membangkitkan motivasi belajar siswa kelas 2 SD Muhammadiyah 1 Candi di tengah pandemi covid 19.[4]

\section{Hasil dan Pembahasan}

Muhammadiyah merupakan gerakan yang bergerak dalam bidang pendidikan selain sebagai gerakan dakwah islamiyah. Manifestasi gerkan Muhammdiyah banyak yang mengakar pada bidang pendidikan. Muhammadiyah sebagai pergerakan yang memajukan ajaran islam yang murni, Muhammadiyah juga telah memberikan sumbangan yang besar di bidang kemasyarakatan dan Pendidikan [5]. Pendiri Muhammadiyah, K.H. Ahmad Dahlan merupakan tokoh pelopor berdirinya sekolah modern. Sejak tahun 1911 Kyai Dahlan telah mendirikan sekolah yang diberi Madrasah Ibtidaiyah Diniyah Islamiyah. Sekolah ini merupakan cikal bakal tumbuhnya pendidikan Muhammadiyah di kemudian hari. Pendidikan Islam modern itulah yang di belakang hari diadopsi dan menjadi lembaga pendidikan umat islam secara umum [5].

Selama masa pandemi covid 19, pemerintah menetapkan pembelajaran jarak jauh atau secara daring. Sebagaimana dalam Surat Edaran Nomor 4 Tahun 2020 tentang Pelaksanaan Kebijakan Pendidikan dalam masa darurat penyebaran virus Corona, yang menginstruksikan pembelajaran dilakukan dari rumah dengan ketentuan pembelajaran dilaksanakan secara online atau jarak jauh. Pembelajaran online pada dasarnya adalah pembelajaran jarak jauh (PJJ) [1]. SD Muhammadiyah 1 Candi menyikapi kebijakan tersebut dengan menerapkan pembelajaran online. Dalam pelaksanaannya, hampir sama seperti pembelajaran offline dengan jam belajar sesuai dengan kondisi pembelajaran offline sebelumnya, hanya saja lebih singkat menjadi 3040 menit per sesi, dengan memanfaatkan aplikasi atau fitur virtual meeting seperti google meet, zoom meeting, dan Microsoft team sebagai sarana interaksi guru dan siswanya. Jadi seolah-olah sekolah seperti biasa, namun tempat dan sarananya berbeda yakni dari rumah.

Strategi dalam pembelajaran daring haruslah tepat dan mampu meningkatkan motivasi belajar siswa pada masa seperti ini, sebab siswa cenderung memaknai belajar daring sebagai libur sekolah karena pembelajaran dilaksanakan di rumah. Oleh sebab itu guru harus lebih memberikan pemahaman mengenai pembelajaran daring dan memberikan motivasi agar anak terus semangat dalam belajar meskipun via daring. Strategi yang digunakan adalah inkuiri dimana rangkaian kegiatan pada pembelajaran, menekankan pada mencari dan menemukan secara mandiri hasil atau jawaban dari suatu masalah, oleh karena itu proses berpikir secara kritis dan analitis sangat ditekankan.

Pada kelas 2 SD Muhammadiyah 1 Candi terdapat total 27 anak dengan 4 diantaranya adalah ABK. Kerjasama yang baik antara orang tua dan guru sangat diperlukan pada masa ini untuk membantu anak dalam proses pembelajarannya. Strategi yang diterapkan yakni dengan menghindari adanya PR dan menyiasatinya dengan mengerjakan secara bersama-sama saat proses belajar mengajar secara virtual. Hal itu dilakukan karena, pada masa anak kelas 2 merupakan masa anak masih bermain sehingga penekanannya hanya pada proses membaca dan menulis. Selain itu, strategi lain yang digunakan pada pembelajaran darig di SD Muhammadiyah 1 Candi adalah dengan menggunakan game-game edukatif, kuis, dsb. Karena dengan game atau bermain seperti ini cenderung mampu membuat anak tidak bosan sehingga motivasi belajarnya pun meningkat. Ada kalanya anak bercerita saat zoom meeting pembelajaran berlangsung, dan sebagai guru harus mendengarkan ceritanya namun langsung di ploting agar tidak memakan 
waktu lama saat proses pembelajaran berlangsung. Anak yang cenderung tidak direspon akan membentuk konsep diri yang negative. [6]

Adapun metode yang digunakan adalah metode diskusi, pendidik dapat memancing siswa dengan memanggil nama peserta didik satu persatu. Media yang digunakan selama daring adalah dengan video yang digunakan untuk indikator menghafal dan memahami. Pelajaran yang paling susah dijelaskan adalah matematika. Karena ada beberapa materi yang perlu untuk dijelaskan menggunakan arat peraga langsung. Seperti pengukuran, kilometer kilogram dll, solusinya adalah mengadakan home visit. Selain itu untuk memotivasi siswa belajar Matematika, maka menggunakan rumus-rumus yang mudah. Adapun solusi bagi siswa yang tidak memiliki handphone adalah dengan sekolah tatap muka dengan menerapkan prokes yang ketat.

\section{Kesimpulan}

Selama masa pandemi covid-19, SD Muhammadiyah 1 Candi menerapkan kebijakan pembelajaran secara online. Kebijakan ini diterapkan atas peraturan pemerintah yang menginstruksikan pembelajaran dilakukan dari rumah yang bertujuan untuk menekan penyebaran covid-19. Selama pelaksanan pembelajaran online, SD Muhammadiyah 1 Candi memanfaatkan zoom meeting dan google meeting sebagai sarana pembelajarannya. Meskipun pembelajaran dilakukan secara online, SD muhammadiyah 1 Candi tetap antusias selama proses pembelajaran berlangsung. Cara guru SD Muhammadiyah 1 Candi memotivasi peserta didik dengan menggunakan metode games, tanya jawab yang melalui kolom komentar zoom meeting. Pembelajaran online ini dilakukan sesuai dengan jam sekolah semestinya, hanya saja lebih di singkat menjadi 30-40 menit per sesi. Guru juga menghindari pemberian tugas kepada peserta didik, karena pada dasarnya peserta didik SD masih dalam usia bermain. Dengan strategi yang telah digunakan mendapat respon yang positif dari peserta didik, salah satunya peserta didik lebih aktif.

\section{Ucapan Terima Kasih}

Dengan terselesaikannya Karya Ilmiah ini penulis mengucapkan terima kasih yang sedalamdalamnya kepada Allah S.W.T atas limpahan karunia dan hidayahnya sehingga penulis dapat melaksanakan penelitian dan menyelesaikan Karya Ilmiah. Bapak Dosen Muhlasin Amrullah,M.Pd.I selaku Dosen kami atas bimbingan, arahan dan koreksinya selama penyusunan dan penulisan Karya Ilmiah. Ustadzah Amelia selaku guru SD Muhammadiyah 1 Candi yang telah bersedia menjadi narasumber dalam penulisan Karya Ilmiah. Teman-teman yang saling mendukung dalam mengerjakan Karya Ilmiah ini.

\section{References}

[1] Belawati, Tian. (2020). Pembelajaran Online. Tangerang Selatan: Universitas Terbuka

[2] Witri Lestari (2015). Efektivitas Strategi Pembelajaran dan Motivasi Belajar Terhadap Hasil Belajar Matematika. Journal Ilmiah Pendidikan MIPA 2 (3)

[3] Yusuf, A. Muri (2014). Metode Penelitian: Kuantitatif, Kualitatif, dan Penelitian Gabungan. Jakarta: KENCANA.

[4] Hardani. (2020). Metode Penelitian Kualitatif \& Kuantitatif. Yogyakarta: Pustaka Ilmu. 
[5] Nashir, Haedar. (2016). Muhammadiyah Gerakan Pembaruan. Yogyakarta: Suara Muhammadiyah

[6] Fauzi, M. (2020). Strategi Pembelajaran Masa Pandemi COVID-19. Jurnal Al-Ibrah, 2(2) $120-16$.

Retrieved

from https://ejournal.stital.ac.id./index.php/alibrah/article/view/104/88 